\title{
ICT SUPPORTED KNOWLEDGE TRANSFER FOR AGRICULTURAL EXTENSION
}

\author{
A Case in China
}

\author{
Weizhe Feng ${ }^{\mathrm{a}}$, Yanqing Duan ${ }^{\mathrm{b},{ }^{*}}$, Zetian $\mathrm{Fu}^{\mathrm{a}}$, Brian Mathews ${ }^{\mathrm{b}}$ \\ "China Agricultural University, 100083, Beijing, China \\ ${ }^{b}$ University of Luton, LUI 3JU, Luton, UK \\ * Corresponding author. Tel.: 00441582 743134; fax: 00441582743926 \\ Email address: yanqing.duan@luton.ac.uk.
}

\begin{abstract}
This paper offers a qualitative study of the applications of ICT in supporting knowledge transfer for the enhancement of modern agricultural extension. To address the challenge, this paper applies an inter-disciplinary approaches to review, analysis and develop a knowledge transfer model, and to conducts an empirical verification of it. A framework is proposed to illuminate the knowledge transfer process, and its associated channels.
\end{abstract}

Key words: Information and communication technology (ICT), knowledge transfer, knowledge brokering, agricultural extension, P.R. China

\section{INTRODUCTION}

Information and communication technology (ICT) is seen as a powerful means of catalysing the formation of knowledge societies in rural areas of the developing world (Meera et al. 2004). As ICT has a growing role in agricultural extension, more systematic research is called for in the exploration and analysis of ICT applications. A review of the literature found that in the context of knowledge management there is no commonly accepted framework for the analysis of ICT supported knowledge transfer for agricultural extension. This paper aims to apply knowledge management theories for a development of an ICT-based knowledge transfer framework.

In the perspective of social research methods, epistemological and ontological views are two of major influences on study (Bryman, 2004). In knowledge management study, an epistemological approach investigates the nature of knowledge itself and looks at knowledge as an entity with discrete 
and relevant attributes. An ontological approach views knowledge as a 'black box' and defines it through relationships, with a systematic account of existence. This view is further extended that epistemological and ontological perspectives have a high potential for synergy (Gebert, et al. 2003). The strategy of this study is to adopt this approach to evaluate knowledge transfer with dynamic changes of knowledge itself and involving relational interactions.

The paper starts with critical review on concepts and theories related to knowledge transfer. With the support of communication theories further classification of tacit knowledge is given. With the incorporation of transfer process and channels a conceptual framework is theoretically constructed using flow charts and a matrix representing processes and channels. On the basis of the evidence collected in a case study in China, the framework is empirically tested. The final conclusion highlights the implications related to the framework and its limitations.

\section{Transferring tacit knowledge with ICT}

A well accepted classification of knowledge is given by Polanyi (1962: ) who divides knowledge into the explicit and the tacit. Explicit knowledge could be codified and communicated in human created scientific or linguistic symbols, Tacit knowledge can be very difficult to articulate but may be communicated through direct human interactions. Researchers may have no doubts about the ability and efficiency of ICT in facilitating explicit knowledge transfer, but they may debate on the transferability of tacit knowledge through ICT.

Bolisani and Scarso (1999) studied cases of ICT applications implemented in Italy and argued that ICT can accomplish all sorts of knowledge transfer tasks, including the transfer of tacit knowledge. Blumentritt and Johnston (1999) and Boutellier et al. (1998) argue that ICT is not able to transfer knowledge directly, but can assist the transfer process. They believe that ICT actually transfers the information but information will be decoded into knowledge by the receiver. Empirical evidence from ICT supported international virtual NPD projects by, Cummings and Teng (2003) led them to argue that ICT is effective at facilitating codified knowledge transfer but could not transfer related 'sensory information', such as feelings, intuition, and non-verbal communications. Roberts (2000) predicts that future advanced ICT may provide the context at the same as richness of face-to-face contact, which may really see the 'death of distance'.

In the context of studying ICT supported knowledge transfer, it is argued that importance needs to be attached to both information and communication. From one perspective the knowledge transfer process could be regarded as the process of communication (Shin, 2001). Furthermore, 
communication is fundamental to knowledge transfer (Riusala and Suutari, 2004) and to all knowledge management process (Quintas, 2002). The theoretical basis of communication study should therefore not be undervalued in the context of in information and dknowledge management.

In conventional theory, human communication could be defined into verbal and non-verbal communication. The former is affected by words both oral and written and the later by means without codes of linguistic symbols (Knapp and Hall, 1997). For the success of non-verbal communication, three primary factors are regarded as important. They include (1) physical environment, e.g. lights, temperature, additional noises etc., and spatial environment or proxemics; (2) communicators' physical appearances, e.g. smell, hair, skin colour, tones etc.; (3) body movement and position, e.g. gestures, posture, touching behaviour, facial expressions, eye behaviour, etc. (Knapp, and Hall, 1997). It is quite clear that electronic transmission might have no way to transfer fully all such elements nor any closely associated instinctive feelings.

In the electronic communication school, media richness theory predominantly explains the transferability of ICT in support of human communication (Daft and Lengel, 1984, 1986). Employing the theory, DeRosa et al. (2004) further classify ICT supported human communication into seven categories that are adapted into figure 1. The layers in two triangles are constructed to explain the richness of communication means between two communicators. The overlapping areas in the middle demonstrate a shared context, or face-to-face communication. This model has the advantage of representing the richness of the communication means with areas of each layer within the triangle.

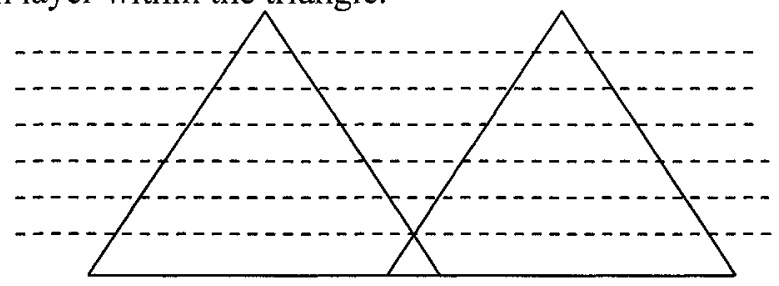

Figure 1. The richness of communication means adapted from DeRosa et al. (2004)

Some knowledge management literature has also attempted to classify the knowledge in accordance with its richness. Sunaoshi et al. (2005) recommend two constructs that affect the transfer of tacit knowledge. They include (1) drawability, for encoding knowledge into two-dimensional representations (signs, pictures, diagrams etc.) which might be difficult to be articulated in a language; and (2) demonstrability for doing ... on the floor' or performing the task together simultaneously. More specifically McCreadie and Rice (1999) draw a distinction between electronic medium transferable 
knowledge and all other knowledge dimensions. The ICT transferable knowledge is classified with those being represented on video-or audio-tape, videodisc, CD-ROM, internet or other electronic and computer media.

Knowledge transfer may be conducted with direct or indirect human interactions (Sveiby, 1996; Hlupic et al. 2002). In terms of direct knowledge transfer, it indicates the direct face-to-fact interaction (FTF) between people and indirect transfer where no such interaction has taken place. Based on the communication richness theory, together with suggestions on classification of knowledge transfer into direct and the indirect, one may be able to further classify tacit knowledge into indirect-tacit (pictorial knowledge transferable with ICT) and direct-tacit (transferable only with co-presence and co-location, or FTF). With this classification it may be possible to better explain the questions raised previously on the capability of ICT in transferring tacit knowledge.

\section{Knowledge transfer, creation and conversion}

In cognitive research, researchers recognise that knowledge transfer is a cognitive process and claim that knowledge creation and transfer can occur simultaneously. It is argued that new knowledge is dynamically created by the receiver when interpreting the transferred knowledge with his personal perception (Holden and Kortzfleisch, 2004; Garavelli et al. 2002).

Nonaka's knowledge creation/conversion theory (Nonaka 1991, Nonaka et. al., 1996; Nonaka et. al., 1998; Nonaka et. al., 2000) is also adopted by other researchers (e.g. Bolisani and Scarso, 1999; Dayasindhu, 2002; Holden and Kortzfleisch, 2004) as knowledge transfer theory. The former illustrates that the knowledge creation process calls for dynamic conversion between the explicit and the tacit. The later claims that the process of knowledge creation/conversion is also taking place when knowledge is being transferred, that is, the transfer and creation/conversion are inseparable. This point of view coincides with the position of Sparkes and Miyake (2000), who argue that knowledge transfer, absorption and assimilation take place sequentially but as a continuous process.

Based on the new contributions and accounts of the sub-division of tacit knowledge, direct and indirect tacit knowledge, Nanaka's knowledge creation/conversion theory could be further modified into a transfer-creation/conversion process, shown in a matrix in Table 1.

Table I. The matrix of knowledge transfer-creation/conversion process

\begin{tabular}{clll}
\hline Transfer-conversion & \multicolumn{1}{c}{ Explicit } & \multicolumn{1}{c}{ Indirect tacit } & \multicolumn{1}{c}{ Direct tacit } \\
\hline Explicit & Explicit-to-explicit & Explicit-to-indirect tacit & Explicit-to-direct tacit \\
Indirect tacit & Indirect tacit-to-explicit & Indirect tacit-to-indirect tacit & Indirect tacit-to-direct tacit \\
Direct tacit & Direct tacit-to-explicit & Direct tacit-to-indirect tacit & Direct tacit-to-direct tacit \\
\hline
\end{tabular}




\section{Towards developing a knowledge transfer framework}

Between the knowledge source and receiver, a third party may be called as intermediary, bridge-maker or negotiator (individuals and/or organizations) for initiating, facilitating, channelling and even participating in interactions (Sverrisson 2001; Hargadon 2002; Matson et al. 2003).

In the context of transferring scientific knowledge in the agriculture sector, it is evident that in a growing number cases research knowledge based on science alone may not necessarily be accepted as correct knowledge by farmers (Burgess et al. 2000). The extensionist is the major source of knowledge and a crucial link to rural knowledge community (Rees et al. 2000; Rivera and Qamar 2003). Therefore, when scientific knowledge is transferred through ICT to the local farmers, field extensionists may act as local decoders and interpreters for knowledge retrieved from ICT. Such an approach was found by Cecchini and Scott (2003) who reviewed major ICT projects in India and Weiss et al. (2000), who studied transfer of agro-meteorological information and knowledge projects world wide.

In addition to the extensionist, all ICT supported knowledge transfer may call for knowledge engineers to acquire and encode domain expert's knowledge for ICT embededdness and transmission. For example, when developing an agricultural expert system, surveys, interviews and case studies are adopted by knowledge engineers for knowledge acquisition from experts. The knowledge base contains text, images, graphics, sound and video sequences (Carrascal et al., 1995). For such knowledge acquisition processes, a broad agreement is that it is impossible to articulate all of the knowledge of an expert explicitly (Wu 1998). However, it is argued that the more indirect tacit knowledge encoded into ICT, the better quality of knowledge being transferred.

In literature, channels of communication are frequently applied in knowledge transfer studies (e.g. Cohen et al. 2002; Holsapple and Joshi 2002). More specifically, channels of knowledge transfer are applied for analysing inter-organisational knowledge transfer activities (e.g. Deardorff and Djankov 2000, Kim et al. 2003). In developing the conceptual framework of this study, the same term is adopted for representing the means by which different dimensions of knowledge being transferred across different knowledge systems. In accordance with the previous classification of tacit knowledge, three channels may appear in an ICT supported knowledge transfer context, namely, the channels for the explicit, the indirect tacit and the direct tacit knowledge.

Nonaka et al. (2000) use two overlapped triangles to demonstrate organisation interactions with business constituents for knowledge creation. With appropriate modifications, two overlapped triangles may be used to 
illustrate the knowledge transfer-creation/conversion between two immediate interactions. In the case scientific knowledge transfer through ICT for agricultural extension, two sorts of immediate interactions may take place: between expert and knowledge engineer and between extensionist and farmer. Two sorts of knowledge transfer are illustrated in figure 2 and 3 with respective three transfer channels.

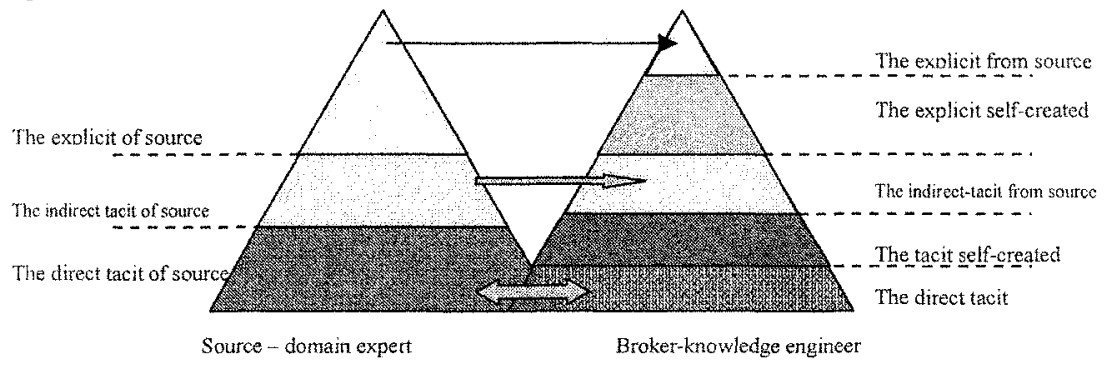

Figure 2. Transfer-creation/conversion process between source and knowledge engineer

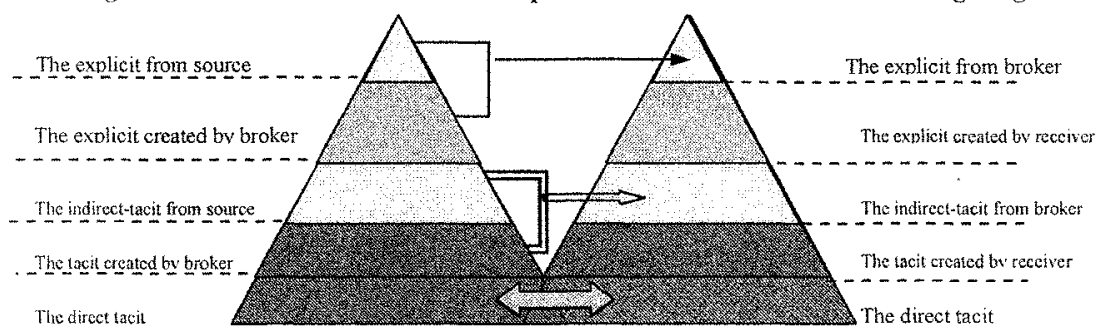

broker-extensionist

end receiver

Figure 3. Transfer-creation/conversion process between extensionist and farmer

According to the conceptual development, a framework of ICT supported knowledge transfer for agricultural extension could be defined as two stages of transfer, through which the scientific knowledge is acquired and encoded by the knowledge engineer firstly, and then being decoded and interpreted to farmer by the extensionist. The ICT acts in the middle with a crucial role in linking knowledge engineer and extensionist effectively and efficiently.

To analyse the creation/conversion of different knowledge dimensions, the modified Nonaka's knowledge transfer-creation/conversion process is adopted into the framework. To have synergic link of the ontological and epistemological approaches, previously developed knowledge transfer channels are adopted into the framework as well. The framework is shown in Figure 4. Two spirals below the triangles are used to represent the transfer-creation/conversion process with three dimensions of knowledge, the explicit, the indirect tacit and the direct tacit. 


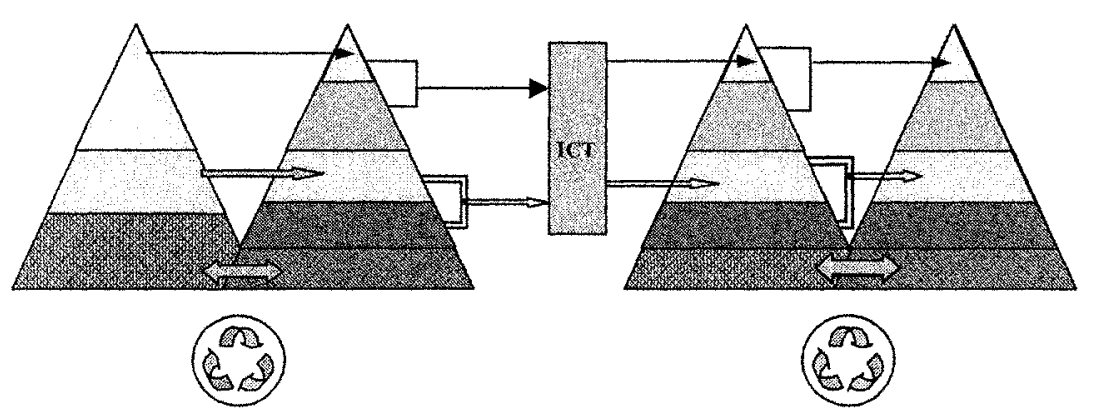

Figure 4. The framework of knowledge transfer for agricultural extension

\section{A case study}

The case study methodology is employed since it best fits empirical inquiry that investigates bounded contemporary phenomena based on the real life context (Yin 2003). The methodology made it possible to examination of the ways a conceptual framework is shaped in accordance with the specific circumstances of applications over similar projects.

To reach a triangulation analysis in the findings, this research is based on information collected from three major sources in the case: in-depth interviews, project review documents and direct observation.

Compared with the vast population engaged in agricultural production in China, the supply of agricultural extension service is fairly low. It is reported that the average ratio of extensionist to farming households in service is about 1: 1200 (Yan et al., 2000). In coping with an insufficient supply in the area of agricultural extension services, the government attaches a great importance in the development of ICT technology toward developing greater efficiency in agricultural extension. Projects are launched by one of the leading state organisations in Beijing for conducting ICT supported extension projects around the country.

The web-based expert systems projects initiated by the organisation demonstrate a dynamic integration of exogenous scientific knowledge and endogenous local knowledge for agricultural extension. A web-based expert system is designed with the target of high performance of local internet infrastructure together with high capability of local extension agency in their continuing building and operating the system. A great advantage of the system is that it allows local extensionist to further modify and upgrade the knowledge base through the Platform of Agricultural Information Development (PAID), a built-in tool of the extension system, in accordance with local farming context. With the support of the government, the project has been implemented in more than fifty provincial project sites around the 
country. The localised expert systems can provide knowledge and help to various farming production such as grains, fruits, vegetables and husbandries. The projects structure and knowledge flow are shown in Figure 5.

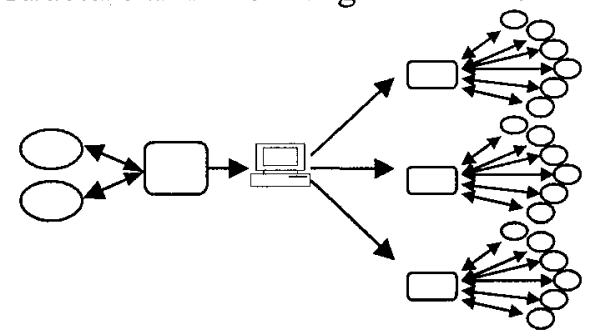

Figure 5. Web-based expert system projects

In the project, the knowledge engineers determines the flexibilities of domain knowledge being embedded into the knowledge base of the system with consideration of the local context. The system differs in the various areas of agricultural production, each system also varies in accordance with related domains. The role of extensionist in such project is very challenging, because considerable computer skills are required to further develop the system toward localisation.

The knowledge transfer-creation/conversion process and channels of knowledge transfer are analysed in table 2 and 3.

Table 2. Knowledge transfer-creation/conversion process

\begin{tabular}{|c|c|c|}
\hline Process & Conducted by knowledge engineer & Conducted by extensionist \\
\hline $\begin{array}{l}\text { Explicit } \\
\text { to } \\
\text { Explicit }\end{array}$ & $\begin{array}{l}\text { It is most signification process to be } \\
\text { studied. In the knowledge base of the } \\
\text { expert system built by engineer, the } \\
\text { majority of terms, definitions, } \\
\text { descriptions, explanations can be traced } \\
\text { back in the source of explicit knowledge, } \\
\text { such as books, working papers and notes } \\
\text { from expert and other published } \\
\text { references. }\end{array}$ & $\begin{array}{l}\text { Text in the original knowledge base is } \\
\text { translated into more localised folk terms. } \\
\text { Sometimes it is printed for distribution, } \\
\text { which is called by farmer the 'plain paper'. } \\
\text { Local farmer's agricultural adages are also } \\
\text { incorporated into the relevant knowledge } \\
\text { base of the system by extensionist. }\end{array}$ \\
\hline $\begin{array}{l}\text { Direct tacit } \\
\text { to } \\
\text { Explicit }\end{array}$ & $\begin{array}{l}\text { There is great endeavour given by a } \\
\text { knowledge engineer to write down what } \\
\text { he learned during the interviews, } \\
\text { meetings and laboratory observations. } \\
\text { This part of the answers may never been } \\
\text { stated explicitly in text by others. }\end{array}$ & $\begin{array}{l}\text { Extensionist corrects and adds a certain } \\
\text { amount of text based knowledge into the } \\
\text { original knowledge base according to his } \\
\text { knowledge and understanding of the local } \\
\text { context. This part counts for the largest } \\
\text { amount of the contents of modifications and } \\
\text { additions to the original knowledge base. }\end{array}$ \\
\hline $\begin{array}{l}\text { Explicit to } \\
\text { Direct tacit }\end{array}$ & $\begin{array}{l}\text { In case agricultural domain experts } \\
\text { raising different opinions to a question, } \\
\text { or a less favoured topics to experts, } \\
\text { knowledge engineer has to search } \\
\text { information and data and relevant } \\
\text { domain knowledge by himself elsewhere } \\
\text { and to finally reach his own } \\
\text { understandings. }\end{array}$ & $\begin{array}{l}\text { Extensionist reads text based knowledge in } \\
\text { the original knowledge base of the expert } \\
\text { system and also actively acquires knowledge } \\
\text { from the accessible books, notes in a specific } \\
\text { topic in learning the scientific knowledge } \\
\text { introduced through the expert system.. }\end{array}$ \\
\hline $\begin{array}{l}\text { Direct tacit } \\
\text { to } \\
\text { Direct tacit }\end{array}$ & $\begin{array}{l}\text { Due to reasons of incentives, domain } \\
\text { language difficulties, and the } \\
\text { complexity of agricultural production } \\
\text { conditions, many blank knowledge }\end{array}$ & $\begin{array}{l}\text { Extensionist frequently communicates with } \\
\text { farmers with interested topics and teaches } \\
\text { farmer the related scientific knowledge that } \\
\text { he has learned through the expert system. He }\end{array}$ \\
\hline
\end{tabular}




\begin{tabular}{|c|c|c|}
\hline & $\begin{array}{l}\text { areas need to be well understand by } \\
\text { knowledge engineer himself through } \\
\text { site visits, interviewing people and } \\
\text { discussion with colleagues } \\
\text { All agricultural domain knowledge has } \\
\text { to be finally interpreted in a rule-based } \\
\text { computing language. On the other hand, } \\
\text { a large amount of personal experience } \\
\text { and inductive knowledge acquired from } \\
\text { the domain expert may not be reflected } \\
\text { rigorously in the rule based system. For } \\
\text { such-cross discipline integration of two } \\
\text { knowledge systems the issues have to } \\
\text { be considered over and addressed in the } \\
\text { mind of the knowledge engineer before } \\
\text { the construction of the system. }\end{array}$ & $\begin{array}{l}\text { may also empirically evaluate the } \\
\text { effectiveness of the expert system based on } \\
\text { farmer's opinions and practices. } \\
\text { Supported with some computing skills, the } \\
\text { extensionist also conducts some simple } \\
\text { programming to encode his local exogenous } \\
\text { knowledge into rigorous rule-based } \\
\text { knowledge. For such-cross disciplines } \\
\text { integration of two knowledge systems has to } \\
\text { be well addressed in his mind before his } \\
\text { physical modifications of the expert system. }\end{array}$ \\
\hline $\begin{array}{l}\text { Indirect tacit } \\
\text { to } \\
\text { Explicit }\end{array}$ & $\begin{array}{l}\text { Academically derived charts, diagrams, } \\
\text { pictures, animations and videos } \\
\text { sometimes need to be simplified into less } \\
\text { academic based text by knowledge } \\
\text { engineers. }\end{array}$ & $\begin{array}{l}\text { Extensionist sometimes find it necessary to } \\
\text { interpret those charts, diagrams, pictures, } \\
\text { animations and videos in the expert system } \\
\text { with local folk terms orally or producing } \\
\text { 'plain paper'. }\end{array}$ \\
\hline $\begin{array}{l}\text { Explicit } \\
\text { To } \\
\text { Indirect tacit }\end{array}$ & $\begin{array}{l}\text { Descriptive text is understood and is } \\
\text { developed into Charts, diagrams, } \\
\text { pictures, animations and videos. }\end{array}$ & $\begin{array}{l}\text { Difficult concepts and process are interpreted } \\
\text { into cartoons, charts and diagrams for the } \\
\text { ease of farmer's understanding. }\end{array}$ \\
\hline $\begin{array}{l}\text { Direct tacit } \\
\text { to } \\
\text { Indirect tacit }\end{array}$ & $\begin{array}{l}\text { Observed diagnostic phenomena or best } \\
\text { practices are explained or demonstrated } \\
\text { in charts, diagrams, pictures, animations } \\
\text { and videos into the system }\end{array}$ & $\begin{array}{l}\text { Observed local best practices are explained } \\
\text { or demonstrated in charts, diagrams, } \\
\text { pictures, cartoons and videos in the } \\
\text { modification of the expert system }\end{array}$ \\
\hline $\begin{array}{l}\text { Indirect tacit } \\
\text { to } \\
\text { Direct tacit }\end{array}$ & $\begin{array}{l}\text { Charts, diagrams, pictures, animations } \\
\text { and videos acquired help engineer to } \\
\text { understand the domain knowledge }\end{array}$ & $\begin{array}{l}\text { Charts, diagrams, pictures, animations and } \\
\text { videos in the expert system help the } \\
\text { extensionist to understand the domain } \\
\text { knowledge }\end{array}$ \\
\hline $\begin{array}{l}\text { Indirect tacit } \\
\text { to } \\
\text { Indirect tacit }\end{array}$ & $\begin{array}{l}\text { Charts, diagrams, pictures, animations } \\
\text { and videos acquired are re-edited or } \\
\text { modified by knowledge engineer }\end{array}$ & $\begin{array}{l}\text { Charts, diagrams, pictures, animations and } \\
\text { videos in the original knowledge base are } \\
\text { further re-edited or modified by extensionist }\end{array}$ \\
\hline
\end{tabular}

\section{Table 3. Knowledge transfer channels}

\begin{tabular}{|c|c|c|}
\hline \multicolumn{2}{|l|}{ Channels } & \multirow{2}{*}{$\begin{array}{l}\text { Description } \\
\text { A large amount of text based knowledge on books, notes are collected } \\
\text { by domain expert for knowledge engineer }\end{array}$} \\
\hline $\begin{array}{l}\text { Channels for } \\
\text { transfer explicit } \\
\text { knowledge }\end{array}$ & $\begin{array}{l}\text { Expert to } \\
\text { knowledge } \\
\text { engineer }(K E)\end{array}$ & \\
\hline & $\begin{array}{l}\mathrm{KE} \text { to } \\
\text { extensionist }\end{array}$ & $\begin{array}{l}\text { A large amount of text based knowledge on books, notes are retrieved } \\
\text { and edited into the knowledge base by knowledge engineer during } \\
\text { web-based expert system building } \\
\text { Knowledge engineer has to derive rules and process explicitly that have } \\
\text { never been done before for building the web-based system } \\
\text { Both categories of text based knowledge in the system are } \\
\text { electronically transmitted to and retrieved by extensionist }\end{array}$ \\
\hline & $\begin{array}{l}\text { Extensionist } \\
\text { to farmer }\end{array}$ & $\begin{array}{l}\text { All text based built-in knowledge in the web-based knowledge system } \\
\text { is retrieved by extensionist according to farmer's request or retrieved by } \\
\text { farmer directly. } \\
\text { The extensionist has to modify some text in the knowledge base in } \\
\text { accordance with the local context. The extensionist also use his } \\
\text { integrated exogenous and indigenous knowledge to produce a piece of } \\
\text { 'plain paper' for farmers' convenient use }\end{array}$ \\
\hline $\begin{array}{l}\text { Channels for } \\
\text { transfer }\end{array}$ & Expert to $\mathrm{KE}$ & $\begin{array}{l}\text { Charts, diagrams, pictures, animations and videos are collected by } \\
\text { domain expert for the knowledge engineer }\end{array}$ \\
\hline
\end{tabular}




\begin{tabular}{|c|c|c|}
\hline \multirow[t]{2}{*}{$\begin{array}{l}\text { indirect-tacit } \\
\text { knowledge }\end{array}$} & $\begin{array}{l}\text { KE to } \\
\text { extensionist }\end{array}$ & $\begin{array}{l}\text { Charts, diagrams, pictures, animations and videos are retrieved and } \\
\text { edited into the knowledge base of the system by knowledge engineer } \\
\text { Knowledge engineer has to produce a certain amount of charts, } \\
\text { diagrams, pictures, animations and videos that were not available but } \\
\text { important for the knowledge base building } \\
\text { Both categories of charts, diagrams, pictures, animations and videos } \\
\text { based knowledge in the system are electronically transmitted to and } \\
\text { retrieved by extensionist }\end{array}$ \\
\hline & $\begin{array}{l}\text { Extensionist } \\
\text { to farmer }\end{array}$ & $\begin{array}{l}\text { All charts, diagrams, pictures, animations and videos in the expert } \\
\text { system are retrieved by extensionist according to farmer's request. } \\
\text { - The extensionist has to modify some charts, diagrams, pictures and } \\
\text { videos in the knowledge base in accordance with local context. }\end{array}$ \\
\hline \multirow{3}{*}{$\begin{array}{l}\text { Channels for } \\
\text { transfer } \\
\text { direct-tacit } \\
\text { knowledge }\end{array}$} & Expert to KE & $\begin{array}{l}\text { - Intensive face-to-face interactions between agricultural experts and } \\
\text { knowledge engineer throughout the system development }\end{array}$ \\
\hline & $\begin{array}{l}\mathrm{KE} \text { to } \\
\text { extensionist }\end{array}$ & $\begin{array}{l}\text { Some intensive fact-to-face training programmes delivered by } \\
\text { knowledge engineer in helping extensionist get familiar with the } \\
\text { knowledge base and operation of the system }\end{array}$ \\
\hline & $\begin{array}{l}\text { Extensionist } \\
\text { to farmer }\end{array}$ & $\begin{array}{l}\text { Intensive FTF interactions between extensionist and farmer for } \\
\text { integration of exogenous and indigenous during the application of the } \\
\text { web-based expert system }\end{array}$ \\
\hline
\end{tabular}

\section{Conclusions and implications}

A framework of the ICT supported knowledge transfer for agriculture extension is proposed in this study. It offers an analytical tool for designing, explaining, analysing and evaluating how ICT applications can support scientific knowledge transfer to farmers. The framework is based on synergic incorporation of epistemological and ontological approaches. The transfer-creation/conversion process may help expert system designers to project, trace and assess the different dimensions of knowledge in terms of its quantity, quality and dynamic changes. The transfer channel formulates the structure of knowledge base and applications of ICT means.

With the proposed classification of tacit knowledge into the indirect and direct, the framework facilitates channels for their respective transferring Transferring indirect knowledge remains ignored by many researchers. Such ignorance, to some extent, misleads the attention of ICT applications towards developing more effective computing systems. Although the relevant research interests has appears in literature and pilot application (e.g. Duan et al. 2003; Carrascal et al. 1995), indeed, other indirect tacit knowledge transfer channels, e.g. mass media like TV that are popularly available in the rural areas, have not yet drawn enough attention in both academic and practical world. In China, interactive TV programmes via internet or text-message of mobile phone are very popular. But there is no agricultural extension projects have been initiated to adopt this advance technology. It is suggested by Weiss et al. (2000) that 'multiplier effects' may be achieved by linking the internet based knowledge transfer with mass media toward a more effective result.

The limitation of the framework is its focus on knowledge transfer process and channels. In terms of knowledge transfer, use of advanced ICT 
technology can not guarantee an effective knowledge interpretation, assimilation and application (Bolisani and Scarso 1999, Meera et al., 2004). This argument implicates that further study of the knowledge transfer context and influential factors are called for. The second limitation of this framework rests its coverage on implementation of knowledge transfer by knowledge engineer and extensionist rather than knowledge absorption process by farmers. If the knowledge transfer process is considered as two-stages, knowledge transmission by source and absorption by receiver (Garavelli et al. 2002, Forsman and Solitander 2003), it may call for future research endeavour to be conducted in the learning process of farmers in absorbing knowledge from the ICT means directly or from an ICT equipped extensionist.

\section{REFERENCES:}

[1] Blumentritt, R. and Johnston R. (1999). "Towards a Strategy for Knowledge Management." Technology Analysis \& Strategic Management Vol. 11, No. 3: 287-300

[2] Bolisani, E. and Scarso E. (1999). "Information technology management: a knowledge-based perspective." Technovation(19): 209-217

[3] Boutellier, R., Grassmann, O., Macho, H., Roux, M., (1998) Management of dispersed product development teams: the role of information technologies. R\&D Management 28: 13-25

[4] Bryman, A. (2004). Social research methods, 2nd ed. New York, Oxford University Press. pp 21

[5] Burgess, J., Clark, J. et al. (2000). "Knowledges in action: an actor network analysis of a wetland agri-environment scheme." Ecological Economics 35: 119-132

[6] Carrascal, M., Pau, L. et al. (1995). "Knowledge and information transfer in agriculture using hypermedia: a system review." Computers and electronics in agriculture Vol. 12: 83-119

[7] Cecchini, S. and Scott C. (2003). "Can information and communications technology applications contribute to poverty reduction? Lessons from rural India." Information Technology for Development 10: $73-84$

[8] Cohen, G, Salomon, I., et al. (2002). "Information-communications technologies (ICT) and transport: does knowledge underpin policy?" Telecommunications Policy 26:31-52

[9] Cummings, J, and Teng B.S. (2003). "Transferring R\&D knowledge: the key factors affecting knowledge transfer success." Journal of Engineering and Technology Management(20): 39-68

[10] Daft, R. L. and Lengel R. H. (1984). "Information richness: A new approach to managerial behavior and organizational design." Research in organizational behavior 6: 191-233

[11] Daft, R. L. and Lengel R. H. (1986). "Organizational information requirements, media richness, and structural design." Management Science Vol. 32, No.5: 554-571

[12] Dayasindhu, N. (2002). "Embeddedness, knowledge transfer, industry clusters and global competitiveness: a case study of the Indian software industry." Technovation 22: 551-560

[13] Deardorff, A. and Djankov S. (2000). "Knowledge Transfer Under Subcontracting; Evidence from Czech Firms." World Development Vol. 28, No. 10: 1837-1847

[14] DeRosa, D. M., Hantula, D. A. et al. (2004). "Trust and leadership in virtual teamwork: A media naturalness perspective." Human Resource Management Vol. 43, No. 2 \& 3: 219-232

[15] Duan, Y., Fu, Z. et al. (2003). "Toward developing and using Web-based tele-diagnosis in aquaculture." Expert Systems with Applications Voi. 25: 247-254

[16] Forsman, M and Solitander N. (2003). "Knowledge transfer in clusters and networks - An interdisciplinary conceptual analysis." Journal of international business studies-www.jibs.net-2003. http://copenhagen.jibs.net/LitReview/2003/2003_3_24.pdf

[17] Garavelli, C., M. Gorgoglione, et al. (2002). "Managing knowledge transfer by knowledge technologies." Technovation 22: 269-279.

[18] Gebert, H., Geib, M. et al. (2003). "Knowledge-enabled customer relationship management: integrating customer relationship management and knowledge management concepts." Journal of knowledge management Vol. 7, No.5: 107-123

[19] Hargadon, A. (2002). "Brokering knowledge: linking learning and innovation." Research in organizational behavior Vol, 24; $41-85$

[20] Hlupic, V., Pouloudi, A., et al. (2002). "Towards an Integrated Approach to Knowledge Management: 'Hard', 'Soft' and 'Abstract' Issues." Knowledge and Process Management Vol. 9, No. 2: 90-102 
[21] Holden, N. J. and Kortzfleisch H. F. (2004). "Why Cross-Cultural Knowledge Transfer is a Form of Translation in More Ways than You Think." Knowledge and Process Management Vol. 11: 127-136

[22] Holsapple, C. W. and Joshi K. D. (2002). "Knowledge manipulation activities: results of a Delphi study." Information \& Management 39: 477-490

[23] Kim, S., Hwang, H. et al. (2003). "AProcess-based Approach to Knowledge-Flow Analysis: A Case Study of a Manufacturing Firm." Knowledge and Process Management Vol.10, No.4: 260-276

[24] Knapp, M. and Hall J. (1997). Nonverbal communication in human interaction, 4th ed. Fort Worth, TX, Harcourt Brace. pp 5, 11

[25] Li, D., Fu, Z. et al. (2002). "Fish-Expert: a web-based expert system for fish disease diagnosis." Expert Systems with Applications 23: 311-320

[26] Matson, E, Patiath, P. et al. (2003). "Stimulating Knowledge Sharing: Strengthening Your Organization's Internal Knowledge Market." Organizational Dynamics Vol. 32, No. 3: 275-285

[27] Maxwell, J. (1996). Qualitative Research Design, An Interactive Approach. Thousand Oaks, SAGE. pp17

[28] McCreadie, M. and Rice R. E. (1999). "Trends in analyzing access to information. Part I: cross-disciplinary conceptualizations of access." Information Processing and Management 35: 45-76

[29] Meera, S. N., Jhamtani, A. et al. (2004). "Information and communication technology in agricultural development: A comparative analysis of three projects from India." ODI: Agricultural Research \& Extension Network, Network Paper No. 135

[30] Nonaka, 1. (1991). "The knowledge-creating company." Harvard Business Review on Knowledge Management (paperback), Harvard Business School Press, Boston 21-46

[31] Nonaka, I., Umemoto, K. et al. (1996). "From Information Processing to Knowledge Creation: A Paradigm shift in Business Management." Technology In Society Vol.18, No.2: 203-218

[32] Nonaka, I., Reinmoeller, P. et al. (1998). "The 'ART' of Knowledge: Systems to Capitalize on Market Knowledge." European Management Journal(16): 673-684.

[33] Nonaka, I., Toyama, R, et al. (2000). "SECI, Ba and Leadership: a Unified Framework of Dynamic Knowledge Creation." Long Range Planning(33): 5-34.

[34] Polanyi, M. (1962). Personal knowledge. London, Routledge. pp. 92

[35] Quintas, P., Ed. (2002). Managing knoweldge in a new century. In Little et al. (ed.) Managing knowledge. An essential reader. pp 1-14. London, Sage Publications

[36] Rees, D., Momanyi, M. et al. (2000). "Agricultural knowledge and information system in Kenya-implications for technology dissemination and development." Agricultural Research \& Extension Network, Network Paper No.107, http://www.odi.org.uk/agren/papers/agrepaper 107.pdf. Retrieved on 16, Jan., 2004

[37] Riusala, K. and Suutari V. (2004). "International Knowledge Transfers through Expatriates." Thunderbird International Business Review Vol. 46 (6): 743-770

[38] Rivera, W. M. and Qamar M. K. (2003). Agricultural extension, rural development and the food security challenge. Rome, FAO. pp. ii

[39] Roberts, J. (2000). "From Know-how to Show-how? Questioning the Role of Information and Communication Technologies in Knowledge Transfer." Technology Analysis \& Strategic Management Vol. 12, No. 4: 429-443.

[40] Shin, M., Holden, T. et al. (2001). "From knowledge theory to management practice: towards an integrated approach." Information Processing and Management(37): 335-355

[41] Song, J., Hu, R, et al. (1998). "An analysis of farmer's behaviour on agricultural technology." Agricultural Technology and Economics (6) : 36-44 (in Chinese)

[42] Sparkes, J. R. and Miyake M. (2000). "Knowledge transfer and human resource development practices: Japanese firms in Brazil and Mexico." International Business Review 9: 599-612.

[43] Sunaoshi, Y., Kotabe, M. et al. (2005). "How technology transfer really occurs on the factory floor: a case of a major Japanese automotive die manufacturer in the United States." Journal of World Business 40 : $57-70$

[44] Sveiby K.E. (1996). "Transfer of Knowledge and the Information Processing Professions." European Management Journal 14, No. 4: 379--388.

[45] Sverrisson, A. (2001). "Translation Networks, Knowledge Brokers and Novelty Construction: Pragmatic Environmentalism in Sweden." ACTA Sociologica 14: 313-327

[46] Weiss, A., Crowder, L. V. et al. (2000). "Communicating agrometeorological information to farming communities." Agricultural and Forest Meteorology 103:185-196

[47] Wu, X. (1998). "Explicit schematic information in knowledge representation and acquisition." Expert Systems with Applications 15: 215-221

[48] Yan J., et al. (2000). "Agricultural Expert and the diffusion of knowledge in the agriculture sector." Journal of Tsinghua University-Philosophy and Social Sciences Vol.15, No. 1: 57-61 (in Chinese)

[49] Yin, R. (2003). Case study research design and methods, 3rd ed. Thousand Oaks, SAGE. pp 13, 116 